\title{
Infant feeding in the third world
}

\author{
G.J. Ebrahim \\ Reader in Tropical Child Health, Institute of Child Health (University of London), 30 Guilford Street, London \\ WCIN IEH, UK.
}

\section{The biological value of human breast milk}

During the last decade a great deal of scientific research has helped to establish the biological value of human breast milk. Starting with the nutrient and anti-infective properties we have now come to realise that breast milk is a live substance carrying at least two different populations of living cells - each with a distinct biological property of its own (Ogra \& Ogra, 1978). Furthermore, the mother's milk contains substances which influence a number of physiological functions in the infant including the endocrine metabolic responses (Lucas et al., 1980) and the absorptive processes in the gut (Ebrahim, 1982, 1985). As a result many research workers now look upon breast milk not merely as a source of nourishment but also as a biological mediator of a number of functions in the newborn. In this respect the mammary gland in the human continues to provide the same sustenance and support for the newborn as the placenta does for the fetus.

The paediatric profession has been quick to grasp the significance of this research and, in Britain certainly, the promotion of breast feeding has come to be an important part of paediatric care. In all the leading neonatal units in Britain early feeding of the newborn with human breast milk is now established as a significant part of neonatal care. This is particularly so for those babies who need intensive care. Where the mother's milk is not available pooled donor milk is used for the purpose. Over the past several years a great deal of research and technological innovation have gone into the setting up of milk banks for the storage of human milk in conditions which cause the least deterioration of protective substances.

Health education of the public and the formation of national bodies like the La Leche League together with changes in hospital routines have led to a marked upsurge in breast feeding. Britain today can be described as essentially a breast feeding nation.

By comparison we see a different scenario in the

Correspondence: G.J. Ebrahim, F.R.C.P. (Ed. \& Glas.).
Third World. Breast feeding has been on the decline for the past 20 years or so, and in the case of some countries drastically so (World Health Organization, 1981). 'Modernisation' has been blamed. Education of women and their entry into the labour force in increasing numbers have also been put forth as reasons. However, Sweden, Britain and the United States are all 'modernised' nations. Women play significant roles in the labour force in these countries, and are active in professional and public life. In most Western countries the educated women and those from the professional and upper classes are most likely to breast feed their babies, and also feed them for a longer period, compared to those with less education or from a working class background.

How has present scientific knowledge affected the development of breast milk substitutes? It is true that infant formulae have become more safe. Conditions like idiopathic hypercalcaemia and hypernatraemia are now things of the past. Unmodified cow's milk formulae are no longer used in infant feeding, and instead low-electrolyte low-protein formulae are recommended. However safe our present day products may be, it is important to bear in mind that at any given time the quality of a baby food is as good as the science and technology at that time; also that the road to good breast milk substitutes is strewn with the tombstones of products once heralded as scientific advances and later discarded as defective or dangerous.

\section{Milk substitutes in the Third World}

In the Third World the situation is different. Many products unacceptable in the Western market are on sale there. In the absence of strong governmental controls, consumer pressure and professional vigilance, bottle feeding is taken lightly with disastrous results. Currently the United Nations' Children's Fund (UNICEF) estimates that 1 million infant deaths occur annually in the Third World on account of bottle feeding (UNICEF, 1984). Three main dangers 
have been identified: (1) Those arising from the nonavailability of protective substances of breast milk to the infant. (2) Those arising from the contamination of the feed in a highly polluted environment of poverty, and because of the ignorance of simple principles of hygiene. (3) Those arising from overdilution of feeds on account of the costs of the baby foods.

Market forces and competition led the manufacturers of baby foods to stake their claims to the wide open markets of the Third World. Almost all of them adopted undesirable promotional methods. The ensuing uproar culminated finally in an International Code of Ethics being adopted at the 33rd World Health Assembly under the auspices of the World Health Organisation. The matter should have rested there. Unfortunately some manufacturers have come up with their own codes, and have persuaded governments to adopt alternative codes. The dividing line between a free market and a free for all can be very narrow. But that is how 'Big Business' likes to interpret democracy unless kept in firm check by a strong government. At present, 33 governments have banned all advertising of breast-milk substitutes to the public; 17 countries are running mass media campaigns to promote the advantages of breast milk; 18 countries have brought in national codes to regulate the marketing of powdered milk and 34 more are drafting legislation.

The present situation with regard to infant feeding in the Third World should be considered in the context of international developments as described above, and also in the light of several social and demographic processes. Most Third World countries have seen their populations double during the past two decades. At the current rates of growth in population up to $80 \%$ of humanity will be living in the Third World by the end of the century. This may sound like a tempting market for the surplus stocks of milk in the European Community and the United States. The second demographic phenomenon of social and political significance is the unprecedented increase in the growth of the urban population in most developing countries. Urban shanty towns and slums are springing up in every major city of the developing world. Fully 40 to $50 \%$ of the population in most countries today consist of the urban poor and it is in these families that bottle feeding can be at its most dangerous. The national health and social services have failed to respond adequately to the challenge of urban growth. Whilst such services are gradually being developed, the Third World needs to ensure that the baby food industry can put social responsibilities before profits. In the absence of enlightened marketing policies being followed by the baby food industry the accusing finger must continue to point at those who are persisting in promoting infant formulae in communities where their use can be dangerous.

\section{Human milk as a national resource}

In many developing countries national planners and economists are beginning to look upon human milk as an important national resource. For example in Indonesia (Rohde, 1982) it has been calculated that, on conservative estimates, mothers' milk has a net market value of US $\$ 400$ million, not counting the savings in health and fertility reduction directly attributable to lactation and adding a further US $\$ 120$ million to the economy. It exceeds the value of tin and coffee which were amongst Indonesia's major exports in 1978. Prior to that Ebrahim (1975) had calculated for Tanzania that if breast feeding were to decline by $20 \%$ in that country the cost in terms of imported infant formula would be equal to the total health budget in 1960. Similar calculations have been made for several other countries all pointing to the importance of human milk as a national resource. Furthermore, unlike other national resources in the developing world, which remain largely confined in the urban areas serving the needs of the elite, this resource is easily accessible in the rural areas and also to the urban poor. Hence the need for nations and governments to conserve the resource and protect it from erosion. The need for a network of services to ensure the nutrition and health of pregnant and lactating women, is obvious, and is recognized internationally in the GOBI (Growth promotion, Oral rehydration, Breast feeding and Immunization) programme of the Uniteo Nation's Children's Fund.

The question of adequacy of breast milk output in malnourished mothers is being raised continually. Several studies of energy intake during infancy seem to indicate that with a typical mean output of $800 \mathrm{ml} /$ day of breast milk some supplementary feeding is necessary between 4-6 months but rarely so before the age of 3 months (Whitehead et al., 1982). A similar conclusion was reached by Underwood \& Hofvander (1982) after reviewing data from several developing countries. There are, however, several pitfalls in such generalizations. Firstly there is the large individual variation with some infants consuming twice as much milk as others. This variation in intake can be accounted for by differences in body size and in velocity of growth. But there may also be differences in metabolic efficiency. Moreover, milk composition and output may not be solely due to maternal diet and metabolic make-up. In some instances they may reflect the specific metabolic needs of the infant, for example, the preterm infant (Gross et al., 1981). Secondly, all calculations attempting to relate the nutritional adequacy of breast milk to infant age have relied upon the WHO/FAO estimates of energy requirements which have been thought to err on the higher side (Whitehead, 1983). Because of the present resurgence of interest in breast feeding, exclusive breast feeding 
for prolonged periods of time has become more common in Western Europe and North America. This has provided an opportunity to compare breast milk outputs between mothers in such well-nourished communities and those from the relatively undernourished communities of Africa and Asia. In Canadian mothers, breast milk output varies from $793 \pm 71 \mathrm{ml} / 24 \mathrm{~h}$ at age 3-4 months to $815 \pm 97 \mathrm{ml} / 24 \mathrm{~h}$ at age $7-8$ months (Chandra, 1981). By comparison in Zairean mothers the output ranged from $775 \pm 216 \mathrm{~g} / 24 \mathrm{~h}$ at 0-2 months to $675 \pm 200 \mathrm{~g}$ at age 6-8 months (Henart et al., 1983) and in the Akamba (of Kenya) it ranged from $778 \mathrm{ml} / 24 \mathrm{~h}$ at age $0-1 \mathrm{month}$ to $643 \mathrm{ml} /$ $24 \mathrm{~h}$ at age $0-5$ months (Wil et al., 1981). Growth measurements in the infants of the Canadian mothers showed adequate growth for the first 3 months using the NCHS standards but slightly less thereafter, particularly beyond the age of 6 months. More interestingly with similar milk intakes some infants showed adequate growth and some a faltering of growth, indicating individual differences in requirements (Chandra, 1982). Among the Akamba women lactation performance varied from mother to mother, and in the same mother from day to day. Frequency of feeding and total volume consumed by the infants increased as the infants grew older and weaning commenced. Moreover, night feeding and volume consumed turned out to be as important as daytime feeding. These studies stress the individual variations between requirements and outputs, and each mother-infant pair must be considered separately.

\section{Adequacy of breast milk}

One important outcome of longitudinal studies in lactation in developing countries has been the recognition of seasonal variations in output amongst rural women, especially the effects of physical labour associated with dwindling food intake during the rainy season (Roberts et al., 1982). In the Gambia, the mean daytime breast milk intake of infants aged 12-18 months decreased by approximately $50 \%$ during the early farming season, as also did the time spent by the mothers on child care. A wider appreciation of such seasonal influences on lactation is necessary for appropriate counselling and intervention.

Thus with regard to the question of adequacy of breast milk there are many gaps in our knowledge. There are differences in circumstances, life-styles and environmental influences between the industrial societies of the West and the peasant communities of the developing world as well as amongst the urban poor. There can be no single answer. Each community must be studied separately, and those of us involved in scientific research in one environment should resist the temptation of extrapolating the results to communities and societies with a different set of circumstances. This is more so when we talk about weaning.

In the West, once weaning is commenced there is a progressive decrease in breast feeding with eventual cessation. In developing countries weaning poses a dilemma on account of the danger of contamination (Hibberd \& Golden, 1981), and the low nutrient content of the pap or gruel being offered as the first weaning food. Most such gruels contain in excess of $85 \%$ water (Brandtzaeg et al., 1982) with an average energy content of $1 \mathrm{cal} / \mathrm{g}$. Under these situations breast milk with an energy content of $6 \mathrm{cal} / \mathrm{g}$ solid matter becomes a major source of energy and other nutrients. A longitudinal study of infant growth in Uganda showed that in the second year of life those children who had been taken off the breast consumed $25 \%$ less energy even though the intake of other foods like cow's milk, fruits and cereal was increased by about 60\% (Rutishauser, 1975). Thus breast milk is an important source of energy and of animal protein even in the second year of life in communities where poverty, poor hygiene, ignorance and low level of home technology preclude the use of commercial weaning foods. Under such radically different circumstances the role of the paediatrician is to tailor nutritional counselling to the home circumstance, the level of awareness and the financial resources of the individual family.

At the wider community and national levels there are other challenges which paediatricians in the Third World face besides the scientific and clinical ones mentioned above. Should they restrict their activities only to treating patho-physiology encountered in the clinical situation, or should they be also concerned with the social, economic and political issues affecting the lives of children? Should such a concern be limited by national boundaries or should it be international? In his professional life Otto Wolff put the welfare of children before everything else. An astute clinician, a capable negotiator, and an untiring advocate of children's welfare internationally, he set an example to his students and colleagues. Much of his teaching was directed at focusing the mind on the practicalities of infant feeding at the level of the family and the community, and identified the pitfalls of generalizations. 


\section{References}

BRANDTZAEG, B., MALLESHI, N.G., SVANBERG, U., DESIKACHAR, H.S.B. \& MELLANDER, O. (1982). Dietary bulk as a limiting factor for nutrient intake - with special reference to the feeding of pre-school children. Journal of Tropical Pediatrics, 27, 184.

CHANDRA, R.K. (1981). Breast feeding, growth and morbidity. Nutrition Research, 1, 25.

CHANDRA, R.K. (1982). Physical growth of exclusively breastfed infants. Nutrition Research, 2, 275.

EBRAHIM, G.J. (1978). In Breastfeeding: the Biological Option. p. 82. Macmillan Press: Basingstoke and London.

EBRAHIM, G.J. (1982). Human breast milk: a mediator of biological functions. Journal of Tropical Pediatrics, 28, 2.

EBRAHIM, G.J. (1985). Breast milk and the absorptive process. Journal of Tropical Pediatrics, 31, 2.

GROSS, S.J., GELLER, J. \& TOMASELL, R.M. (1981). Composition of breast milk from mothers of pre-term infants. Pediatrics, 68, 490.

HENART, P., RUCHABABISHA, M. \& VIS, H.L. (1983). Breast feeding and post-partum amenorrhoea in central Africa 3. Milk production in an urban area. Journal of Tropical Pediatrics, 29, 185.

HIBBERT, J.M. \& GOLDEN, M.H.N. (1981). What is the weanling's dilemma? Dietary fecal bacterial ingestion of normal children in Jamaica. Journal of Tropical Pediatrics, $27,255$.

LUCAS, A., BLACKBURN, A.M., AYNSLEY-GREEN, A., SARSON, D.L., ADRIAN, T.E. \& BLOOM, S.R. (1980). Breast vs. bottle - Endocrine responses are different with formula feeding. Lancet, i, 1267.

OGRA, S.S. \& OGRA, P.L. (1978). Immunologic aspects of human colostrum and milk. II Characteristics of lymphocyte reactivity and distribution of E-rosette forming cells at different times after the onset of lactation. Journal of Tropical Pediatrics, 92, 550.

ROBERTS, S.B., PAUL, A.A., COLE, T.J. \& WHITEHEAD, R.G. (1982). Seasonal changes in activity, birthweight and lactation performance in rural Gambian women. Transactions of the Royal Society of Tropical Medicine and Hygiene, 76, 668.

ROHDE, J.E. (1982). Mother milk and the Indonesian economy: a major national resource. Journal of Tropical Pediatrics, 28, 166.

RUTISHAUSER, I.H.E. (1975). The dietary background to protein-energy malnutrition in West mengo district, Uganda. In The Child in the African Environment. Growth Development and Survival, Owor, R., Ongom, V.L. \& Kirya, B.G. (eds). p. 197-201. East African Literature Bureau: Nairobi.

UNDERWOOD, B.A. \& HOFVANDER, Y. (1982). Appropriate timing for complementary feeding of the breast-fed infant: a review. Acta Paediatrica Scandinavica, Suppl. 294, 1.

UNITED NATIONS' CHILDREN'S FUND (1984). State of the World's Children. p. 88. Oxford University Press: Oxford.

WHITEHEAD, R.G., PAUL, A.A. \& COLE, T.J. (1982). How much breast milk do babies need? Acta Paediatrica Scandinavica, Suppl. 29, 43.

WHITEHEAD, R.G. (1983). Nutritional aspects of human lactation. Lancet, 1, 167.

WIL, M., VAN STEENBERG, KUSIN, J.A. \& VAN RENS, M. (1981). Lactation performance of Akamba mothers, Kenya. Breast feeding behaviour, breast milk yield, an composition. Journal of Tropical Pediatrics, 27, 155.

WORLD HEALTH ORGANIZATION (1981). Contemporar patterns of breast feeding. p. 31-46. World Health Organ? isation: Geneva. 